\title{
Breeding ecology and nest aggregations in a population of Salaria pavo (Pisces: Blenniidae) in an area where nest sites are very scarce
}

\author{
Vitor C. Almada*, Emanuel J. Gonçalves*†, António J. Santos* and \\ CÉU BAPTISTA* \\ *Unidade de Investigação em Eco-Etologia, Instituto Superior de Psicologia Aplicada, \\ Rua Jardim do Tabaco 44, 1100 Lisboa, Portugal, and †Laboratório Marítimo da Guia, \\ Faculdade de Ciências de Lisboa, Estrada do Guincho, 2750 Cascais, Portugal
}

(Received 25 June 1993, Accepted 19 December 1993)

\begin{abstract}
In this paper we present data on the breeding ecology and patterns of nest aggregation in a population of Salaria pavo (Pisces: Blenniidae), in an area where hard substrates are very scarce. The study site was at Ria Formosa, an extensive littoral lagoon on the south coast of Portugal. The only hard materials available are bricks, tiles, stones and debris that clam culturists use to delimit their fields. The males of S. pavo establish nests intertidally in the holes of the bricks where they guard the eggs. Data were collected at low tide inspections of these artificial ridges and underwater behavioural observations during high tide. The main results are: (i) the same male can establish sequentially more than one nest in the same breeding season; the number of males that stay within the bricks increases before the start of the breeding season and declines towards its end; (ii) there is a large excess of mature males that do not establish nests and they are significantly smaller than the nesting males, suggesting very strong competition for nest sites; (iii) the nests of several males occur in adjacent holes of the same brick, sometimes being entirely surrounded by other nests. Thus, in this population, there is virtually no defended territory around the nest, a situation not known for other blenniid species. This pattern of nest aggregation implies both strong competition among males and reduction of aggression between neighbour parental fishes. This can be explained by the extreme scarcity and spatial distribution of available nest sites.
\end{abstract}

Key words: nest site competition; intertidal fishes; territoriality; reproductive ecology; nest aggregations; Salaria pavo.

\section{INTRODUCTION}

The males of blenniid fishes typically guard eggs in holes or crevices where females come to spawn. The males actively defend the nest hole and the surrounding area against conspecifics and other intruders (see reviews in Wirtz, 1978; Almada et al., 1983; Thresher, 1984; Heymer, 1987). These territories may extend several tens of centimetres from the nest hole. In some tropical species, territorial behaviour is not restricted to the breeding season and fishes of both sexes may live permanently in individual territories (Fishelson, 1975; Nursall, 1977), a phenomenon never documented for any temperate species.

The behaviour of Salaria pavo (Risso) was studied in the Mediterranean by Fishelson (1963) and Patzner et al. (1986). Fishelson (1963) observed nests of $S$. pavo in Israel, in crevices of rocks, and found that 'the adult males live in permanent individual territories'. This author suggested that this species could

$\dagger$ Author to whom correspondence should be addressed. 
form stable social groups (' reproductive units') since, on different occasions, several fishes appearing to be the same could be found in the same area. Patzner et al. (1986) studied a population of S. pavo in the Adriatic Sea and also found nests in rock crevices but noted that the fishes can use other cavities, including beer cans. They also found that the shortest inter-nest distance was $10 \mathrm{~cm}$, although the males were not in direct visual contact. Moosleitner (1980) mentioned that on a sandy beach in Greece, where hard substrates were scarce, many males congregated under the same boulder during the breeding season, but he provided few details on the breeding ecology of this population. However, this finding suggests that, in conditions where nest sites are scarce and aggregated, the territories of the breeding males can be very small.

A population of $S$. pavo that breeds in a lagoon was found at Ria Formosa (Portugal) where the only hard substrates available are bricks and other debris that form the boundaries of clam cultures. The available nest sites are scarce and locally concentrated. Thus, this population provides an excellent opportunity to study the behaviour of this species under such extreme conditions. In this paper we describe the breeding ecology of this population with special reference to the patterns of nest aggregation.

\section{MATERIAL AND METHODS}

The study area was located at Ria Formosa $\left(36^{\circ} 59^{\prime} \mathrm{N}, 7^{\circ} 5 \mathrm{I}^{\prime} \mathrm{W}\right)$ on the south coast of Portugal. The study site was a lagoon formed by a succession of sand barrier islands and banks that run roughly $50 \mathrm{~km}$ along the coast. Although it is a very sheltered area, several channels ensure that tidal currents keep it in permanent contact with the open sea. The littoral zone of these islands, facing the lagoon, is dominated by sand and mud flats, and dense eelgrass beds are found in the subtidal zone. Almost no rocky substrate is present. The mud flats are used for clam culture, which covers the substrate artificially with a few centimetres of sand and gravel. The boundaries of adjacent clam cultures are delimited by bricks, tiles, stones, and many kinds of hard debris that form little ridges $10-20 \mathrm{~cm}$ high. Alongside the 'clam fields' runs a network of artificial channels consolidated with stones, tiles and sand sacks that establish a permanent connection with the lagoon. Although during low tide, the clam fields stay exposed, the water keeps flowing in and the channels never dry out. The fauna and flora of the clam fields is characteristic of a soft bottom substrate. However, along the ridges it is replaced by a heterogenous community with several species commonly found in rocky intertidal habitats (e.g. Fucus sp., Ulva lactuca, Enteromorpha sp., Chthamalus sp., Gibbula spp., Mytilus galloprovincialis, Patella sp.). It is in this particular habitat that S. pavo are found, being absent from the seaward coast of the sand islands.

All the nests found occurred intertidally in these ridges. Although many individuals move to the channels and adjacent eelgrass beds when the tide ebbs, a substantial number of fishes can also be found out of water during low tide, in the ridges, under stones and tiles and inside bricks.

Field observations were made both during high and low tide in the years 1987, 1988 and 1990. A region, $40 \mathrm{~m}$ in length, of ridges was selected for regular inspection during low tide. Each nest or shelter site was described and its location mapped. The presence of egg masses was also recorded. All the fishes found were captured by a hand net, measured to the nearest $\mathrm{mm}$, sexed by observation of the genital papillae and secondary sexual characters, weighed and marked. Marking was performed by cutting two or three rays of the dorsal fin, according to a predetermined code so that each fish could be recognized individually. At each visit all individuals were inspected for marks and their identity recorded. This procedure took only a few minutes. The fishes were left for a while in clear water and subsequently they were placed exactly where they were found 
TABLE I. Percentage of nesting males, non-nesting males, females and juveniles in bricks and other materials (tiles, stones, etc.) during low tide. Data pooled for all inspections made during the breeding seasons of 1988 and 1990

\begin{tabular}{lccr}
\hline & $\begin{array}{c}\text { Bricks } \\
(\%)\end{array}$ & $\begin{array}{c}\text { Other materials } \\
(\%)\end{array}$ & $\begin{array}{c}\text { Total } \\
(n)\end{array}$ \\
\hline Males with eggs & $97 \cdot 6$ & $2 \cdot 4$ & 124 \\
Males without eggs & $45 \cdot 7$ & $54 \cdot 3$ & 70 \\
Females & $58 \cdot 1$ & $41 \cdot 9$ & 86 \\
Juveniles & 0 & 100 & 2 \\
\hline
\end{tabular}

together with their nests or other shelter objects. No casualties or egg mass destruction were observed and the males continued to guard their nests.

During high tide, focal observations were made by skin-diving, focusing on specific nests or groups of nests. The number of fishes found in each location and their sex (whenever possible) were noted. A total of $13 \mathrm{~h} 6 \mathrm{~min}$ of observation was made.

Statistical analysis of the data was performed using the PC computer program Statgraphics (version 4.0) (Copyright 1985-1989 STSC, Inc. and Statistical Graphics Corporation) and the simulation statistical program Actus (Estabrook \& Estabrook, 1989) designed for the analysis of contingency tables. This program is specially useful to analyse tables with small values that yield very low expected frequencies not meeting the assumptions of standard $\chi^{2}$ tests. It uses random numbers to simulate 1000 tables, each with the same row and column total of the original table. Each simulated table is compared with the original data table. The numbers of cases out of 1000 simulations in which the simulated count for each cell does not exceed the observed count for that cell and the cases in which the observed counts do not exceed the simulated counts, are presented separately. In both situations, values smaller than 50 are one-tailed significant $(P<0.05)$. The significance of $\chi^{2}$ is assessed by the number of times out of 1000 that the value of $\chi^{2}$ for the simulated tables is equal to or greater than that for the original table (Estabrook \& Estabrook, 1989).

\section{RESULTS}

\section{NEST SITE SELECTION}

The nesting males were found almost exclusively in the cavities of the bricks, most of which remain out of water during low tide (Table I). Not all the bricks were used as nests. Only those having one of the ends obstructed and the other opening narrowed, usually by remnants of concrete, were used. Juveniles, females and non-nesting males, on the contrary, were rather less selective concerning the kind of materials under which they sheltered.

There was an excess of nesting males in the bricks and of non-nesting males and females in other materials (Table II). The difference in the use of bricks by nesting males, non-nesting males and females may have been due either to differential substrate preferences or to active exclusion of the other fishes by the nesting males. If so, we would expect that, when the number of nesting males decreased, the number of non-nesting males and females would increase and vice versa, yielding a negative correlation. This was not the case (Spearman rank correlation: $r_{\mathrm{S}}=0.086, P=$ N.S., $n=6$ monthly inspections during the breeding season). 
TABLE II. Statistical analysis of the data shown in Table I using ACTUS. (a) Cases in which the simulated values did not exceed the observed values. (b) Cases in which the observed values did not exceed the simulated values. $\chi^{2}=59 \cdot 372$, d.f. $=3, P<0 \cdot 001$. For details see Material and Methods

\section{Males with eggs Males without eggs Females Juveniles}

\begin{tabular}{|c|c|c|c|c|}
\hline Bricks & 999 & 62 & 27 & 225 \\
\hline Other materials & $0^{*}$ & 994 & 1000 & 977 \\
\hline Bricks & $2^{*}$ & 945 & 981 & 1000 \\
\hline Other materials & 1000 & $11^{*}$ & 2* & 122 \\
\hline
\end{tabular}

${ }^{*} P<0 \cdot 05$ (one tailed).

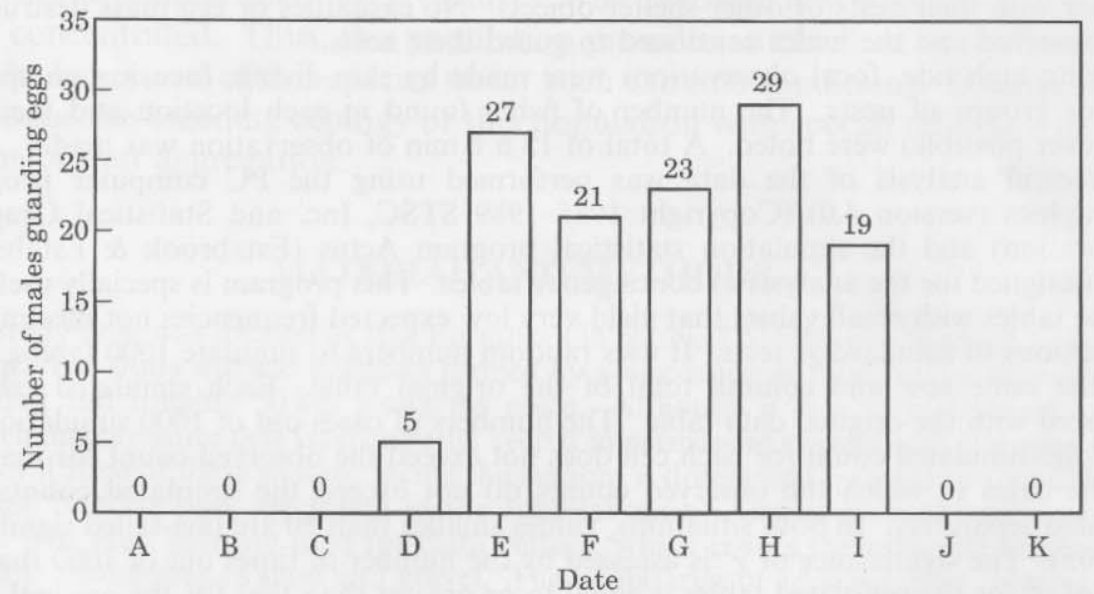

FIG. 1. Numbers of males found guarding eggs at low tide inspections in the years of 1988 and 1990 . The observations are sequenced by months; letters stand for the following dates: A, 12 February 1990; B, 18-20 March 1988; C, 30 March 1990; D, 27 April 1990; E, 20-21 May 1988; F, 25 May 1990; G, 28-29 June 1988; H, 30-31 July 1988; I, 2-3 September 1988; J, 3 October 1988; K, 30 October 1988.

\section{BREEDING SEASON}

The breeding season of this population was studied by monthly inspections of holes used as nests during the years 1988 and 1990 (Fig. 1). Data for the 2 years are presented together since there were not enough monthly observations in each year. This population had a very extended breeding season, starting by the end of April and ending in September. On 27 September 1987 three males were still found guarding eggs (not included in Fig. 1 because data were collected in a different set of ridges). This contrasts sharply with the 2.5 months breeding season (early June to the middle of August) of the Adriatic population studied by Patzner (1983).

\section{TEMPORAL PATTERNS OF NEST OCCUPATION}

The males were not permanent occupants of the nests (Fig. 2). Their number increased with the approach of the breeding season and declined as it ended. Since in 1988 the observations started only in March, this increase before the 


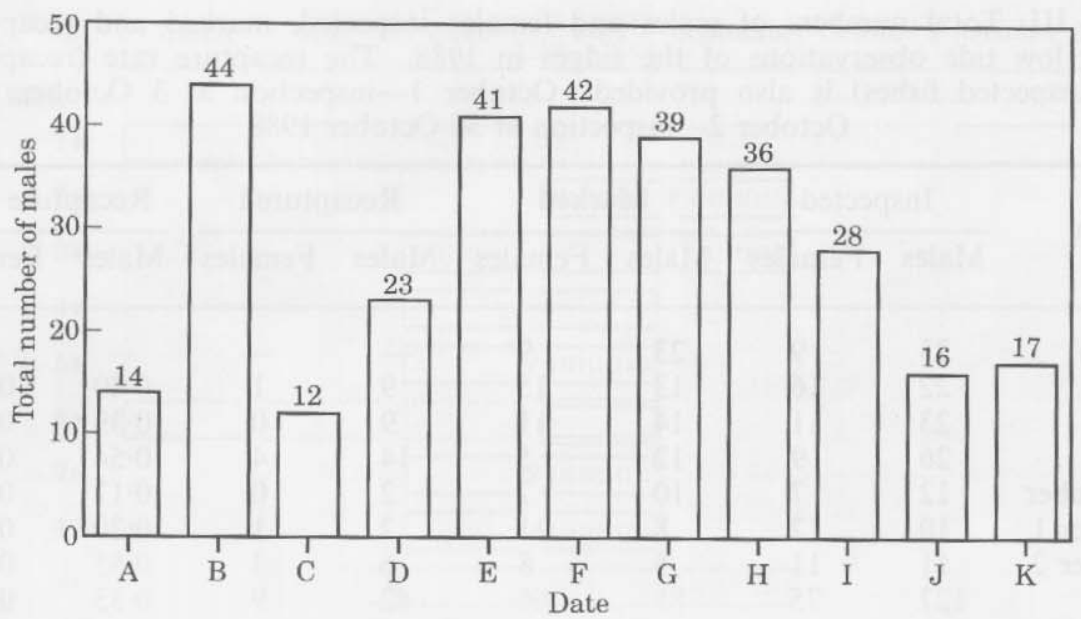

Fig. 2. Total number of males found in the study area at low tide inspections in the years of 1988 and 1990. The observations are sequenced by months; letters stand for the following dates: A, 12 February 1990; B, 18-20 March 1988; C, 30 March 1990; D, 27 April 1990; E, 20-21 May 1988; F, 25 May 1990; G, 28-29 June 1988; H, 30-31 July 1988; I, 2-3 September 1988; J, 3 October 1988; K, 30 October 1988 .

onset of the breeding season was not visible. For reasons that are unclear, there were also differences between the temporal pattern of variation of the number of males between the 2 years studied. While in 1988 the number of males reached its maximum in March, some weeks before breeding had started, in 1990 the number of males continued to increase until May, some weeks after breeding had started.

During the entire breeding season there was always an excess of males that did not guard eggs (compare Figs 1 and 2). The proportion of males guarding eggs ranged from $21 \cdot 7 \%$ in April to $80 \cdot 6 \%$ in July.

\section{SIZE DIFFERENCES BETWEEN NESTING AND NON-NESTING MALES}

The size of the nesting males was significantly greater than that of the non-nesting males (standard length $(\mathrm{cm}):$ mean $=11 \cdot 3$, S.D. $=1 \cdot 11$, range $=8 \cdot 9$ $13 \cdot 4, n=29$, for nesting males; and mean $=9 \cdot 4$, S.D. $=1 \cdot 41$, range $=6 \cdot 8-12 \cdot 9, n=20$, for non-nesting males) (Mann-Whitney test: $Z=-4 \cdot 104, P<0 \cdot 001)$. Active sperm was collected from the vas deferens of the non-nesting males and their gonado-somatic index (GSI) was equal to or greater than that of the nesting males (Almada et al., unpublished), indicating that they were mature. Thus, they represent an excess of mature fishes that did not establish nests.

\section{SEX-RELATED DIFFERENCES IN THE PRESENCE OF FISHES IN THE NESTING AREA}

A total of 151 fishes, 85 males (56\%) and 66 females $(44 \%)$, were marked individually (Table III). These numbers were used to generate expected frequencies of males and females to test the hypothesis that, at the low tides of the breeding season (May to September), the number of fishes inspected ( 83 males and 43 females) was a random sample of the total number of fishes that visited the area. A goodness of fit test showed that, during the breeding season there 
TABLE III. Total numbers of males and females inspected, marked and recaptured during low tide observations of the ridges in 1988. The recapture rate (recaptured fishes/inspected fishes) is also provided. October 1 -inspection at 3 October 1988; October 2 -inspection at 30 October 1988

\begin{tabular}{|c|c|c|c|c|c|c|c|c|}
\hline \multirow{2}{*}{ Month } & \multicolumn{2}{|c|}{ Inspected } & \multicolumn{2}{|c|}{ Marked } & \multicolumn{2}{|c|}{ Recaptured } & \multicolumn{2}{|c|}{ Recapture rate } \\
\hline & Males & Females & Males & Females & Males & Females & Males & Females \\
\hline March & 23 & 9 & 23 & 9 & - & - & - & - \\
\hline May & 22 & 16 & 13 & 15 & 9 & 1 & $0 \cdot 40$ & 0.06 \\
\hline June & 23 & 11 & 14 & 11 & 9 & 0 & $0 \cdot 39$ & 0.00 \\
\hline July & 26 & 9 & 12 & 5 & 14 & 4 & 0.54 & 0.44 \\
\hline September & 12 & 7 & 10 & 7 & 2 & 0 & 0.17 & 0.00 \\
\hline October 1 & 10 & 12 & 8 & 11 & 2 & 1 & $0 \cdot 20$ & 0.08 \\
\hline October 2 & 11 & 11 & 5 & 8 & 6 & 3 & 0.55 & $0 \cdot 27$ \\
\hline Total & 127 & 75 & 85 & 66 & 42 & 9 & 0.33 & $0 \cdot 12$ \\
\hline
\end{tabular}

was a higher percentage of males $(65.9 \%)$ than expected $\left(\chi^{2}=4 \cdot 985\right.$, d.f. $=1$, $P<0 \cdot 05$, data pooled for the total number of low tide inspections). The same comparison for the inspections outside the breeding season did not reveal any significant difference between observed and expected values $\left(\chi^{2}=0 \cdot 111\right.$, d.f. $=1$, $P=$ n.s.).

The recapture rate of males was higher than that of females at each visit (Wilcoxon signed ranks test: $Z=2 \cdot 041, P<0 \cdot 05, n=6$ ). Thus, during low tide, in the breeding season, males tended to stay more consistently than females in the nesting area.

The proportion of the total number of marked females that could be recaptured was significantly lower than that of males (Fisher's exact probability test: $Z=3 \cdot 321, P<0 \cdot 001)$.

Taken together, the results of low tide inspections indicate that the proportion of males that stayed in the nesting area during the breeding season was much higher than that of females, and each individual female tended to stay less frequently in the nesting area than each individual male.

During diving observations, shortly after the tide began to rise, many females and non-nesting males could be seen approaching the nests, moving along the channels and the ridges, indicating that an important fraction of females as well as non-nesting males moved from the adjacent eelgrass beds to the breeding area. To test this hypothesis we compared the numbers of males and females observed in each brick or set of bricks during high tide with the numbers observed in the same sites at low tides of the same month. Since each site was inspected monthly, once at low tide and observed several times during high tides, the counts for all high tide observations of each site were averaged. Data for this analysis were collected at eight sites. Three of them were inspected again in a subsequent month, yielding a total of 11 comparisons. There were significantly more males and more females at high tide observations (males: mean $=6 \cdot 3$, s.D. $=3 \cdot 20$, range $=2 \cdot 3-11 \cdot 3, n=69 \cdot 2$; females: mean $=1 \cdot 9$, S.D. $=1 \cdot 21$, range $=0-4 \cdot 5, n=21 \cdot 0$ ) than at low tide inspections (males: mean $=3 \cdot 5$, S.D. $=2 \cdot 06$, range $=1-7, n=38$; females: mean $=0 \cdot 36$, S.D. $=0 \cdot 48$, range $=0-1, n=4$ ) (Wilcoxon signed ranks test: 


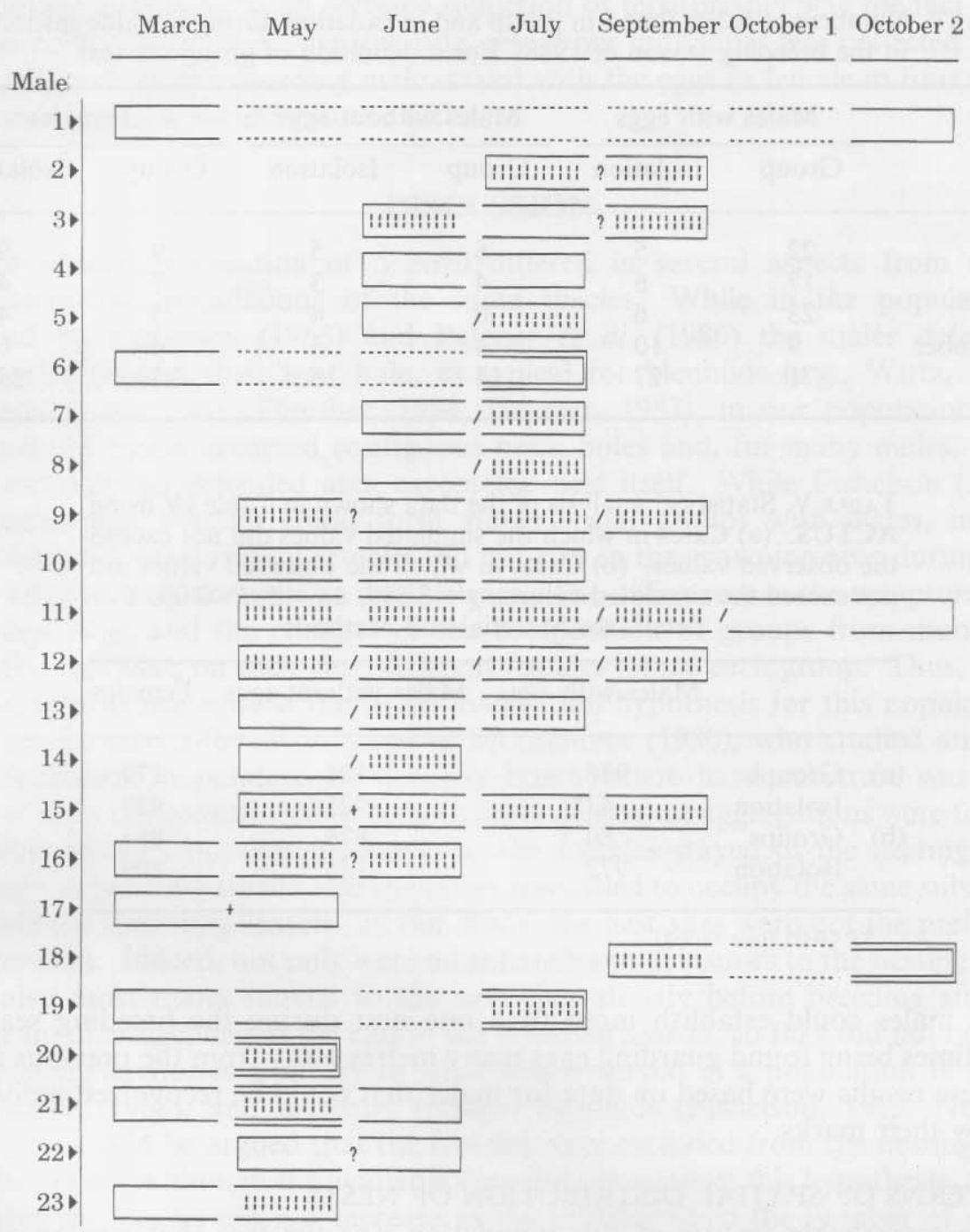

FIG. 3. Data for 23 individually identified males that were followed during low tide inspections in 1988. Symbols are as follows: :in, eggs present in the nest; /, change of hole in the same brick; ?, change of hole uncertain; +, change of hole to another brick; =, change of hole to another ridge, --information missing. October 1, inspection at 3 October 1988; October 2, inspection at 30 October 1988.

$Z=2 \cdot 412, P<0 \cdot 05, n=11$, for males, and $Z=2 \cdot 214, P<0 \cdot 05, n=11$, for females). Note that the numbers of fishes counted at high tide were very conservative, as only those fishes that could be seen simultaneously were considered.

These results confirm that many females and non-nesting males visited the nesting area during high tide, and that the nest sites were not commonly used as shelter by females and non-nesting males during low tide, at least during the breeding season.

Nesting males tended to stay in the breeding area during most of the breeding season, many of them being found in the same nest for 2 or more months (Fig. 3). 
TABLE IV. Numbers of fishes found in group and in isolation during low tide inspections in the breeding season of 1988. For a definition of group see text

\begin{tabular}{|c|c|c|c|c|c|c|}
\hline & \multicolumn{2}{|c|}{ Males with eggs } & \multicolumn{2}{|c|}{ Males without eggs } & \multicolumn{2}{|c|}{ Females } \\
\hline & Group & Isolation & Group & Isolation & Group & Isolation \\
\hline May & 22 & 5 & 6 & 5 & 9 & 9 \\
\hline June & 17 & 6 & 4 & 3 & 7 & 4 \\
\hline July & 23 & 6 & 0 & 4 & 5 & 4 \\
\hline September & 9 & 10 & 4 & 3 & 4 & 6 \\
\hline Total & 71 & 27 & 14 & 15 & 25 & 23 \\
\hline
\end{tabular}

TABLE V. Statistical analysis of the data shown in Table IV using ACTUS. (a) Cases in which the simulated values did not exceed the observed values. (b) Cases in which the observed values did not exceed the simulated values. $\chi^{2}=8 \cdot 889$, d.f. $=2, P<0 \cdot 05$. For details see Material and Methods

\begin{tabular}{|c|c|c|c|c|}
\hline & & Males with eggs & Males without eggs & Females \\
\hline \multirow[t]{4}{*}{ (a) } & Groups & 936 & 191 & 179 \\
\hline & Isolation & $42^{*}$ & 925 & 930 \\
\hline & Groups & 80 & 878 & 865 \\
\hline & Isolation & 972 & 121 & 109 \\
\hline
\end{tabular}

${ }^{*} P<0.05$ (one tailed).

Some males could establish more than one nest during the breeding season, sometimes being found guarding eggs many metres away from the previous nest.

These results were based on data for males that could be recognized individually by their marks.

\section{PATTERNS OF SPATIAL DISTRIBUTION OF NESTS}

One remarkable feature of this population was the fact that nesting males could occur in adjacent cavities of the same brick. Thus, when they were 'head out ' as blenniids typically are, the males were in visual contact, with the nest entrances separated only by the thin brick walls. In some bricks, we found nesting males in cavities almost entirely surrounded by other nests. A fish was classified as being in a group if other fishes were collected from the same brick on the same occasion. The great majority of nests was found in groups with other nesting males (Tables IV and V).

The mean number of nesting males per group was 2.95 (range $=2-6, n=21$ ). Most groups included two or three nesting males, although two groups with six nesting males were found. Moreover, the majority of the nests (65 of 81) was separated from one or more neighbouring nests only by a thin brick wall. Thus we conclude that, for the nesting males of this population, there was no defended area surrounding the nest, contrary to what is typical for blenniid breeding males. 
Another indication of an extreme reduction of territoriality was the fact that, in five nests inspected during low tide, one other individual was collected from the cavity where the guarding male stayed with the eggs (a female in four cases and an unsexed individual in the fifth).

\section{DISCUSSION}

The present population of $S$. pavo differed in several aspects from other Mediterranean populations of the same species. While in the populations studied by Fishelson (1963) and Patzner et al. (1986) the males defended territories around their nest hole, as typical for blenniids (e.g., Wirtz, 1978; Almada et al., 1983; Thresher, 1984; Heymer, 1987), in our population, the majority of males occupied contiguous brick holes and, for many males, there was virtually no defended area except the nest itself. While Fishelson (1963) suggested that females could form stable social groups with males, in our population the majority of females did not stay in the spawning area during low tide, approaching the nests as the tide rose. The differences in the recapture rate between sexes and the changes of the composition of groups from month to month show that, on each visit, different females joined each group. Thus, there is strong evidence against the stable association hypothesis for this population. Our results also differ from those of Moosleitner (1980), who studied another Mediterranean population on a sandy beach where hard substrate was very scarce, as in the present study. In both cases dense nest aggregations were found. In Moosleitner's population, however, the females stayed in the nesting area during the breeding season and the males continued to occupy the same substrate outside the spawning season. In our study, the nest sites were not the preferred shelter sites. Indeed, not only were most females tidal visitors to the nesting area, but also most males moved to the nest sites shortly before breeding started. Their number declined at the end of the breeding season, so they did not occupy permanent territories contrary to what was observed in a population in Israel (Fishelson, 1963), and in many tropical blenniids (Fishelson, 1975; Nursall, 1977). It could be argued that the females were excluded from the nesting area by the males. Although the available data did not support this hypothesis, as the number of females did not increase in the months when the number of males decreased, this subject deserves further investigation in the future.

Except for the extreme reduction of the territories, the data conform to the pattern found in other intertidal blenniids of the temperate eastern Atlantic. Both in Lipophrys pholis (L.) (Gibson, 1967; Almada et al., 1992) and Coryphoblennius galerita (L.) (Almada et al., 1983), the males move to the nesting area only as the breeding season approaches and territoriality ceases at the end of the breeding season. Females are non-territorial throughout the year and no stable groups are known. A similar situation was found in a population of Lipophrys canevae (Vinciguerra) breeding intertidally in the Atlantic coast of Portugal (unpublished data). The same pattern was also found in Parablennius sanguinolentus (Pallas) at the Azores (Santos et al., 1989). In reviewing the biology and behaviour of littoral fishes, Gibson $(1969,1982)$ found that permanent territories are not widespread in intertidal fishes, although in many species home ranges are commonly found. 
We suggest that in conditions where strong tides and seasonality prevail, the ecological factors must exert a strong pressure against permanent territoriality in intertidal fishes with male parental care. Indeed, for a fish to live on a permanent territory centred on a nest site, the defended area must also provide adequate shelter and, if it is to be economically defendable, a consistent availability of food resources throughout the year (Brown, 1964). This is unlikely if food abundance, degree of cover, temperature and other factors vary strongly in their spatio-temporal patterns, as is the case for temperate shores. In these circumstances, it is likely that the best nest site and feeding site do not coincide, as reported for temperate gobies by Magnhagen (1986) and Zander (1990).

The most striking features of our population are the extreme reduction of male breeding territories and the formation of nest aggregations, not yet reported for any other blenniid species. Colonial nesting was reported by many authors (Fishelson, 1970; Bietz, 1981; Gross \& MacMillan, 1981; Ribbink et al., 1981), and its possible functions discussed by Wilson (1975), Loiselle \& Barlow (1978), Krebs \& Davies (1987). Keenleyside (1979) and Turner (1986) discuss teleost breeding systems generally. Gross \& MacMillan (1981) restrict the use of the term coloniality to cases "when proximity is a result of social attraction rather than habitat shortages ... '. The data presented in this paper do not exclude the possibility of active attraction by conspecifics and this issue needs to be resolved in the future by experimental work. However, the nest aggregations that we found seem to be explained easily by the shortage of adequate nest sites and their patterns of spatial distribution, as reported by Moosleitner (1980). As mentioned above, only brick holes with one of the openings obstructed, and the other opening usually narrowed by remains of concrete, were used as nests. These structures were very scarce and concentrated locally in some bricks. Indeed, while most bricks did not satisfy these requirements, some had several adjacent cavities that fulfil them, depending on the circumstances under which they were taken from demolished buildings. The fact that a large proportion of mature males did not establish nests and that those that did were larger than average, suggested strong competition for a limited supply of adequate holes. This hypothesis predicts that nests vacated during the breeding season should be occupied quickly by floater males. Preliminary evidence supports this prediction. In seven nests in which we removed the parental male, four were occupied by another male within $24 \mathrm{~h}$. In contrast to this situation, in a study of $L$. pholis nesting on an area where nest holes were in large supply, vacated nests were never reocccupied during the same breeding season (Almada et al., 1992).

For these male aggregations to be possible, a strong reduction of aggression among neighbouring males must occur. Preliminary observations indicate that, while prior to the start of the breeding season males fight intensely for nest sites, after the males occupy nests, agonistic interactions among neighbouring males are very uncommon. It would be of great interest to perform comparative work in order to determine if this reduction of inter-male aggression represents a genetic trait of this population or if it is an expression of phenotypical behavioural plasticity of this species, in given ecological situations.

Almada et al. (1992) hypothesized that one of the functions of the breeding territories of male blenniids was the defence of a food reserve upon which the parental male can rely. Since, in this population, the territories of the parental 
males were reduced to a minimum (the nest hole), there was no feeding area defended around the nest. Thus, the hypothesis predicts that parental males of this population must rely upon body reserves accumulated before the establishment of the nests, showing a sharper decline in their condition factor throughout the breeding season, when compared with breeding males of populations that control larger territories. Nest aggregations as those described in this paper, should provide an opportunity to test this hypothesis in the future (Almada et al., in preparation).

The present study was supported financially by Serviço Nacional de Parques, Reservas e Conservação da Natureza. The authors are grateful to the following persons and institutions: administration and staff of Parque Natural da Ria Formosa, specially its director Arq. ${ }^{\text {to }}$ Nuno Lecoq; Paula Rito, Carlindo Xavier, Miguel Wallenstein, João Pedro da Conceição, who helped in the field work; Instituto Superior de Psicologia Aplicada and Laboratório Marítimo da Guia; Dra. Teresa Avelar and Teresa Guedes who reviewed the English; Professor Lev Fishelson for his careful review of the manuscript and many helpful suggestions; and two anonymous referees for their useful suggestions and criticisms.

\section{References}

Almada, V., Dores, J., Pinheiro, A., Pinheiro, M. \& Santos, R. S. (1983). Contribuição para o estudo do comportamento de Coryphoblennius galerita (L.) (Pisces: Blenniidae). Memórias do Museu do Mar-Série Zoológica 2, 1-166.

Almada, V., Gonçalves, E. J., de Oliveira, R. F. \& Barata, E. N. (1992). Some features of the territories in the breeding males of the intertidal blenny Lipophrys pholis (Pisces: Blenniidae). Journal of the Marine Biological Association of the United Kingdom 72, 187-197.

Bietz, B. F. (1981). Habitat availability, social attraction and nest distribution patterns in longear sunfish (Lepomis megalotis peltastes). Environmental Biology of Fishes 6, 193-200.

Brown, J. L. (1964). The evolution of diversity in avian territorial systems. Wilson Bulletin 76, 160-169.

Estabrook, C. B. \& Estabrook, G. F. (1989). ACTUS: a solution to the problem of small samples in the analysis of two-way contingency tables. Historical Methods 22, 5-8.

Fishelson, L. (1963). Observations on littoral fishes of Israel. I. Behaviour of Blennius pavo Risso (Teleostei: Blenniidae). Israel Journal of Zoology 12, 67-80.

Fishelson, L. (1970). Behaviour and ecology of a population of Abudefduf saxatilis (Pomacentridae, Teleostei). Animal Behaviour 18, 225-237.

Fishelson, L. (1975). Observations on the behaviour of the fish Meiacanthus nigrolineatus Smith-Vaniz (Blenniidae) in nature (Red Sea) and in captivity. Australian Journal of Marine and Freshwater Research 26, 329-341.

Gibson, R. N. (1967). Studies on the movements of littoral fish. Journal of Animal Ecology 36, 215-234.

Gibson, R. N. (1969). The biology and behaviour of littoral fish. Oceanography and Marine Biology Annual Review 7, 367-410.

Gibson, R. N. (1982). Recent studies on the biology of intertidal fishes. Oceanography and Marine Biology Annual Review 20, 363-414.

Gross, M. R. \& MacMillan, A. M. (1981). Predation and the evolution of colonial nesting in bluegill sunfish (Lepomis macrochirus). Behavioral Ecology and Sociobiology 8, 163-174.

Heymer, A. (1987). Comportement agonistique, stratégies reproductrices et investissement parental chez Blennius basiliscus (Teleostei, Blenniidae). Revue Française d'Aquariologie 14, 89-108. 
Keenleyside, M. H. A. (1979). Diversity and Adaptation in Fish Behaviour. Berlin: Springer-Verlag.

Krebs, J. R. \& Davies, N. B. (1987). An Introduction to Behavioural Ecology. Oxford: Blackwell Scientific Publications.

Loiselle, P. V. \& Barlow, G. W. (1978). In Contrasts in Behaviour (Reese, E. S. \& Lighter, F. J., eds), pp. 31-76. New York: John Wiley \& Sons.

Magnhagen, C. (1986). Activity differences influencing food selection in the marine fish Pomatoschistus microps. Canadian Journal of Fisheries and Aquatic Sciences 43, 223-227.

Moosleitner, H. (1980). Zentrale Laichstelle ermöglicht Blennius pavo, Risso 1810 (Blenniidae, Perciformes, Teleostei) die Besiedlung von Sandgrund. Zoologischer Anzeiger 204, $82-88$.

Nursall, J. R. (1977). Territoriality in redlip blennies (Ophioblennius atlanticus-Pisces: Blenniidae). Journal of Zoology 182, 205-223.

Patzner, R. A. (1983). The reproduction of Blennius pavo (Teleostei, Blenniidae). I. Ovarian cycle, environmental factors and feeding. Helgoländer Meeresuntersuchungen 36, 105-114.

Patzner, R. A., Seiwald, M., Adlgasser, M. \& Kaurin, G. (1986). The reproduction of Blennius pavo. V. Reproductive behaviour in natural environment. Zoologischer Anzeiger 216, 338-350.

Ribbink, A. J., Marsh, A. C. \& Marsh, B. A. (1981). Nest-building and communal care of young by Tilapia rendalli Dumeril (Pisces: Cichlidae) in Lake Malawi. Environmental Biology of Fishes 6, 219-222.

Santos, R. S., Almada, V. C. \& Santos, A. J. F. (1989). Field experiments and observations on homing and territoriality in intertidal blennies. In Ethoexperimental Approaches to the Study of Behaviour (Blanchard, R. J., Brain, P. F., Blanchard, D. C. \& Parmigiani, S., eds), pp. 623-632. Dordrecht: Kluwer Academic Publishers.

Thresher, R. E. (1984). Reproduction in Reef Fishes. Neptune City: T.F.H. Publications.

Turner, G. (1986). Teleost mating systems and strategies. In The Behaviour of Teleost Fishes (Pitcher, T. J., ed.), pp. 253-274. London: Croom Helm.

Wilson, E. O. (1975). Sociobiology: The New Synthesis. Cambridge: Harvard University Press.

Wirtz, P. (1978). The behaviour of the Mediterranean Tripterygion species (Pisces, Blennioidei). Zeitschrift für Tierpsychologie 48, 142-174.

Zander, C. D. (1990). Habitat and prey dependent distribution of sand gobies, Pomatoschistus minutus (Gobiidae, Teleostei), in the SW Baltic. Zoologischer Anzeiger 5/6, 328-341. 